\title{
Blood Mineral Response of Local Duck Fed the Diet Containing Seaweed Gracilaria Sp. Waste and Additives Multienzyme
}

\author{
Nurul Frasiska ${ }^{1}$, Edjeng Suprijatna ${ }^{2}$, Siti Susanti $^{3}$ \\ ${ }^{1}$ Faculty of Agriculture, Study Program Animal Science, Perjuangan University of Tasikmalaya \\ 2,3 Faculty of Animal and Agriculture Science, Diponegoro University \\ Corresponding E-mail : frasiskanurul@gmail.com
}

\begin{abstract}
The study aimed to evaluate the blood mineral of Tegal ducks as a response to diet containing Gracilaria sp. waste and additive multienzyme. The study used 72 laying ducks of 22 weeks old which were allotted to 6 treatments, i.e. (1) control diet, (2) diet with multienzymes, (3) diet with $10 \% \mathrm{GW}$ (4) diet with $10 \% \mathrm{GW}+$ multienzyme, (5) diet with $12.5 \% \mathrm{GW}+$ multienzymes (6) diet with $15 \% \mathrm{GW}+$ multienzyme. Commercial Multienzyme consisted of protease, amylase, pectinase, $\beta$-glucanase, xylanase, phytase, cellulase from Altech (Allzyme SSF) at a dose of $150 \mathrm{~g} \mathrm{/}$ ton of feed. Gracilaria sp. waste was given in the form of meal. The results demonstrated that feed Gracilaria sp. waste and additives multienzymes significantly $(P<0.05)$ increasing the levels of phosphorus, sodium, potassium and iron in the blood of local ducks, but not blood calcium levels ( $P$ > $0.05)$. The use of feed containing seaweed waste multienzyme coupled to a level $15 \%$ gave a good response in the blood mineral levels of local ducks compare to control.
\end{abstract}

Key word: Blood Mineral, Gracilaria sp. waste, Local Ducks, Multienzyme

Abstrak. Penelitian ini bertujuan untuk mengevaluasi respon mineral darah itik tegal yang diberi pakan mengandung Limbah Gracilaria sp. dengan penambahan aditif multienzim. Materi penelitian yang digunakan adalah itik Tegal betina umur 22 minggu sebanyak 72 ekor, limbah budidaya rumput laut Gracilaria sp., dan multienzim komersial yang mengandung 7 macam enzim antara lain protease, amylase, pectinase, $\beta$-glukanase, xylanase, phytase, selulase dari PT. Altech (Allzyme SSF) dengan dosis $150 \mathrm{~g} /$ ton pakan. Penelitian menggunakan Rancangan Acak Lengkap dengan 6 perlakuan yaitu (TO) Ransum Basal, ( $\left.\mathrm{TO}_{+}\right)$Ransum Basal dengan Multienzim, (T1) Ransum dengan 10\% LG (T1+) Ransum dengan 10\% LG + multienzim, (T2+) Ransum dengan 12,5\% LG + multienzim (T3+) Ransum dengan 15\% LG + multienzim. Masing-masing perlakuan diulang 4 kali dan terdapat 3 ekor itik. Hasil menunjukkan bahwa pemberian pakan yang mengandung limbah budidaya rumput laut Gracilaria sp. dan aditif multienzim berpengaruh nyata $(P<0,05)$ terhadap kadar pospor, natrium, kalium dan besi dalam darah itik lokal, tetapi tidak terhadap kadar kalsium darah $(P>0,05)$. Penggunaan pakan mengandung limbah rumput laut ditambah multienzim hingga level 15\% memberikan respon yang baik pada kadar mineral darah itik lokal.

Kata kunci : Mineral Darah, limbah budidaya Gracilaria sp., Itik lokal, Multienzim.

\section{Introduction}

High feed material prices and competition of farmers with feed processing industry to get quality feed ingredients. Need alternative feed ingredients that have abundant availability, the value of good nutrition and economic value. Indonesia has reached $81,000 \mathrm{~km}$ coastline with seaweed cultivation area 769.452 ha (Ministry of Trade, 2013). Total production of seaweed abundant, produce waste that can be used as an alternative feed ingredient for livestock with high nutrient value.

Gracilaria sp. waste is part of the seaweed plant of Gracilaria sp. the result of a sort of seaweed cultivation and has no commercial value to industry (Alamsjah et al., 2011). Gracilaria sp. is one type of algae which contains a gel, where the gel has the ability to bind water is high enough (Sinulingga and Darmanti, 2007) that contains essential 
minerals for the body. Cabrita et al. (2016) describes in her study of the various types of seaweed as a source of minerals, that the mineral content in seaweed achieve 30-39\% dry matter. Essential minerals contained in seaweed by Haryanti et al. (2008), among others, iron, iodine, aluminum, manganese, calcium, soluble nitrogen, phosphorus, sulfur, chlorine. silicon, rubidium, strontium, barium, titanium, cobalt, boron, copper, potassium. According to Shields (2012), types of microalgae such as seaweed has the potential mineral content that can be added to the feed as a provider of organic mineral sources that are easily absorbed. Other content is kind of oligosaccharides Algal-oligosaccharides lysate (AOL) and Neoagaro-oligosaccharides (NAOS) (Wu et al., 2005; Hu et al., 2006). Oligosaccharides in waste Gracilaria sp. has prebiotic properties that are beneficial to microbes in the digestive tract that aid in the absorption of minerals (Patel and Goyal, 2011). Cabrita et al. (2016) examines the advantages of seaweed as a source of minerals for feedstuffs.

Utilization of Gracilaria sp. as poultry feed in accordance with the level of digestibility around $6 \%$ (2.8-6.1\%) (Ochoa et al., 2014) due to limitations of Gracilaria sp. waste as feed for poultry are constituent fiber content is polisacharida form of cellulose (Xylooligosaccharide) (Oktavia et al., 2014). Utilization of Gracilaria sp. waste for poultry as feed is on $10 \%$ in maximum use (Yunita et al., 2015) using biotechnological fermentation, but at higher levels had lower digestibility in the digestive tract due to single cell protein. Single cell protein low digestibility likely the result of non-protein nitrogen content is high (Wang et al, 2013). To increase the level of use for waste to Gracilaria sp. can be an alternative feed ingredient efforts are needed to increase the digestibility of feed ingredients to be an important component in Gracilaria sp. optimally utilized by livestock.
In this research, multienzyme supplementation in order to increase digestibility. Besides, the addition of multienzymes on feed will also improve the quality of feed ingredients making up more rations. Commercial multienzymes consisting of various enzymes will help increase nutrient digestibility by freeing including those bound by the walls of coarse fiber feed ingredient is a prebiotic (Kiarie et al., 2013). The use of commercial multienzymes will increase the level of Gracilaria waste utilization to be more efficient.

Laying duck requires minerals in sufficient quantities in order to produce optimal. The mineral content contained in seaweed waste was expected required of livestock, especially during egg production. Calcium and Phosphor are needed especially during egg production. Potassium and sodium serves as an electrolyte involved in the regulation of acid-base balance. Research on blood minerals is important because the blood plays a role in the transport system of one mineral nutrient. As is well known, the cattle will produce a good product if all the physiological processes that occur in the body takes place normally. Livestock physiological processes are closely linked with biochemical reactions in the body. Therefore, blood mineral levels as one of the manifestations of the ongoing biochemical mechanisms in the cells of the body become one of the important indicators worthy of examination in the search for new breakthroughs to increase the productivity of livestock. Mineral status measurement is to know how much minerals that can be utilized by livestock it showed on their production.

\section{Materials and Methods}

The experiments were performed in 72 Tegal ducks on laying periods. Using 24 traditional cage housing system measures $60 \times 60 \times 75 \mathrm{~cm}$. Gracilaria $s p$. waste given in the form of flour which has been dried and ground. Enzyme 
additive used is a commercial multienzyme contains the enzyme protease, mananase, xylanase, and NSP degrading enzymes Allzyme SSF from Altech at a dose of $150 \mathrm{~g} /$ ton of feed. The composition of the feed material used in the study are iso protein and energy with $18 \%$ iso protein and iso metabolizable energy 2900 $\mathrm{kcal} / \mathrm{kg}$. Composition of the ration study are presented in Table 1.

The design study used a completely randomized design with 6 treatments and 4 replications. Each quiz consists of three ducks so all there are 60 ducks. Study treatment consisting of basal diet (control) (TO), basal diet
+ multienzyme (T0+), diet with $10 \%$ Gracilaria sp. waste (T1), diet with $10 \%$ Gracilaria sp. waste + multienzyme (T1+), diet with $12.5 \%$ Gracilaria sp.waste + multienzyme $(\mathrm{T} 2+)$, diet with $15 \%$ Gracilaria sp.waste + multienzyme (T3+). Ducks kept for 12 weeks. The period of adaptation is performed during the last two weeks followed by a period of rationing treatment. The measured parameters such as blood minerals include calcium, phosphorus, sodium, potassium, and iron. Blood sampling performed at week 12 or at the end of the treatment period.

Table 1. Ingredients and Nutrient Compositions of the Experimental Diet

\begin{tabular}{|c|c|c|c|c|}
\hline Feed material & $\begin{array}{r}\text { T0 } \\
(0 \%) \\
\end{array}$ & $\begin{array}{r}\mathrm{T} 1 \\
(10 \%) \\
\end{array}$ & $\begin{array}{r}\mathrm{T} 2 \\
(12,5 \%) \\
\end{array}$ & $\begin{array}{r}\text { T3 } \\
(15 \%) \\
\end{array}$ \\
\hline Corn & 54.8 & 52.7 & 51.0 & 49.0 \\
\hline Gracilaria sp. & 0 & 10.0 & 12.5 & 15.0 \\
\hline Soybean Meal & 17.2 & 19.7 & 19.7 & 20.0 \\
\hline Oil & 0.8 & 0.2 & 0.2 & 0.4 \\
\hline Ricebran & 14.7 & 4.8 & 4.0 & 3.0 \\
\hline Fish Meal & 7.0 & 8.5 & 8.5 & 8.5 \\
\hline $\mathrm{CaCO}_{3}$ & 1.9 & 1.0 & 1.0 & 1.0 \\
\hline Premix & 1.0 & 1.0 & 1.0 & 1.0 \\
\hline Methionin & 0.4 & 0.4 & 0.4 & 0.4 \\
\hline Lysin & 0.7 & 0.7 & 0.7 & 0.7 \\
\hline Brotiacostulla & 1.0 & 1.0 & 1.0 & 1.0 \\
\hline Total & 100 & 100 & 100 & 100 \\
\hline \multicolumn{5}{|l|}{ Nutrient Composition(\%) } \\
\hline $\mathrm{EM}(\mathrm{kcal} / \mathrm{kg})^{*}$ & 2902.29 & 2923.22 & 2909.41 & 2907.28 \\
\hline Crude Protein (\%)* & 18.05 & 18.17 & 18.15 & 18.25 \\
\hline Crude Fat (\%)* & 8.05 & 7.52 & 7.26 & 7.61 \\
\hline Crude Fiber (\%)* & 6.63 & 5.47 & 5.56 & 5.59 \\
\hline Methionin (\%)** & 1.36 & 0.75 & 0.74 & 0.74 \\
\hline Lysin (\%)** & 0.63 & 1.27 & 1.26 & 1.25 \\
\hline Arginin $(\%)^{* *}$ & 1.24 & 1.24 & 1.22 & 1.20 \\
\hline Calcium $(\%)^{*}$ & 2.78 & 2.02 & 2.03 & 2.03 \\
\hline Phospor (\%)* & 0.73 & 0.69 & 0.89 & 0.68 \\
\hline
\end{tabular}

T1-T3:Treatment with Gracilaria sp. waste (GW)

T0: basal diet.

$\mathrm{T} 1, \mathrm{~T} 2$, and $\mathrm{T} 3: 10 \% \mathrm{GW}, 12,5 \% \mathrm{GW}$, and $15 \% \mathrm{GW}$, respectively.

Energy metabolism (EM) was measured based on the Balton formula.

Nitrogen free extract $=100-(\%$ water $+\%$ ash $+\%$ crude protein $+\%$ crude fat $+\%$ crude fiber $)$.

Energy metabolism $(E M)=40.81\{0.87$ (crude protein +2.25 crude fat + nitrogen free extract +4.9$\}$. 


\section{Collected of Blood Sample and Serum Preparation}

Blood taken $3 \mathrm{ml}$ of the brachial vein sections using a sterile injection syringe and then inserted into the tube and allowed to stand until clotting occurred and separate serum. Serum was taken using a pipette and stored in eppendorf tubes to further analyzed using Spectrophotometry and AAS methods. 0.5 $\mathrm{ml}$ serum samples were taken and then added $4.5 \mathrm{ml}$ TCA (Trichloroacetil acid) 10\% $5 \mathrm{ml}$. Further samples mixed using vortex for a minute and allowed to stand for 30 minutes. The purpose of mixing samples of serum with TCA $10 \%$ is to precipitate the protein. After 30 minutes, the mixture in the centrifuge for 10 minutes.

Phosphorus Analysis. Take $1 \mathrm{ml}$ of this solution, for testing phosphorus use Spectrophotometer. Add a solution of $1 \mathrm{ml}$ and $3 \mathrm{ml}$ aquademin vanadate and fortex for 1 minute. Subsequently allowed to stand for 20 minutes. After 20 minutes the solution is read on spectrophotometer at of $400 \mathrm{~nm}$ wavelength.

Calcium, Potassium, Sodium and Iron Analysis. Sample preparation result after it is taken for testing phosphorus, lanthanum added a solution of $2 \mathrm{ml}$ mixed for 1 minute. Further testing using AAS (Atomic Absorption Spectrophotometer) at a wavelength of 422.7 $\mathrm{nm}$ for calcium, potassium $766.5 \mathrm{~nm}, 589.1 \mathrm{~nm}$ for sodium, and $248.3 \mathrm{~nm}$ for iron. Mineral levels specified in ppm.

Statistical Analysis. Statistical analysis was performed for all measurement data using the SPSS procedures (version 17.0) using analysis of variance (ANOVA). The differences between treatments were tested further using the Least Significant Different test (LSD). Significance level was determined at $\mathrm{P}<0.05$.

\section{Results and Discussions}

Statistical analysis showed that the ration contains the Gracilaria sp. waste had no significant effect on blood calcium levels ( $P>$ $0.05)$ but shows the significant effect $(P<0.05)$ in the levels of phosphorus, sodium, potassium and iron in the blood (Table 2). The highest blood levels of minerals demonstrated by treatment of ration containing $15 \%$ by Gracilaria sp. waste with multienzyme. There is a tendency to increase blood levels of minerals in the ration containing Gracilaria sp. waste with rising levels.

Tabel 2. Content of mineral elements in blood plasma in last-week-old duck with diet containing seaweed waste Gracilaria sp. and additives multienzyme

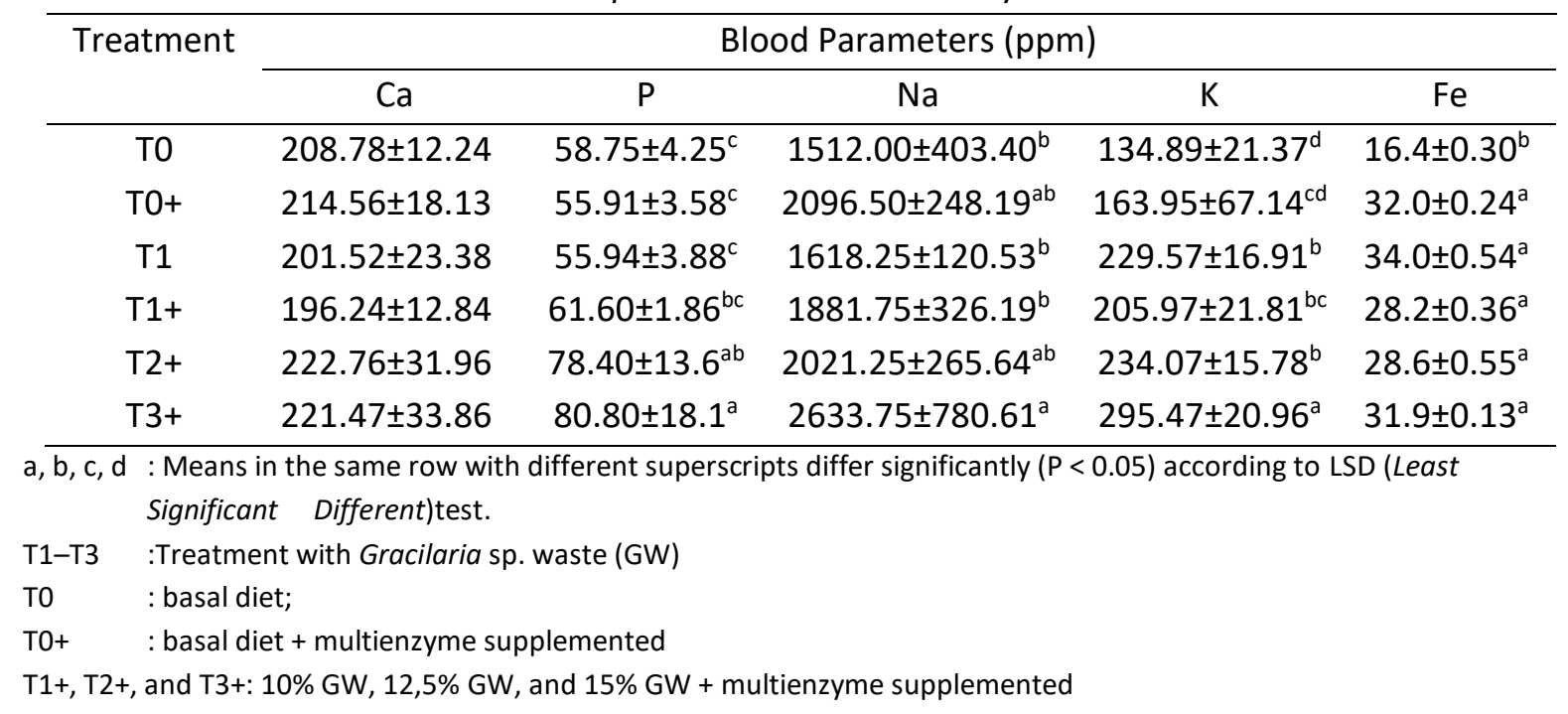


The average feed consumption of local ducks fed with rations containing Gracilaria sp. showed that there was no difference between each treatment (Table 3). This indicates that the amount of mineral consumption contained in the feed is the same. It allows for differences in digestibility between treatments. Feed containing Gracilaria sp. waste and multienzyme supplemented have a better digestibility. The content of oligosaccharides in the Gracilaria sp. eliminated by the addition of multienzyme thus increasing digestibility. Forming part of the Gracilaria sp. waste in the form of cellulose is broken down with the aid of multienzyme so prebiotic oligosaccharides that are working in the gut. According to Wu et al., (2006), the specific content in Gracilaria sp. is NAOS (Neoagaro-oligosacchariders) good in stimulating growth and improving Bifidobactery and Lactobacillus populations in the digestive tract. Activity of lactic acid bacteria in the digestive tract will lower the $\mathrm{pH}$ in the digestive tract so it would be optimal calcium absorption (Abdurrahman, 2016). The use of ration containing Gracilaria sp. waste and multienzyme with increasing levels should be followed by an increase in blood calcium levels. But this does not occur in this study. The use of ration containing LG with multienzyme show had no signifficant effect on blood protein levels. This may be due to feed treatment also did not significantly affect the protein levels in the blood (Table 3).
Normal blood calcium in local ducks is approximately 120-160 ppm (Ariyani, 1997 and Pranata et al., 2015). Duck blood calcium in this study are included in the high category that ranges from 196-222 ppm. This is due to the ducks are in a laying period. Laying birds have the concentration of calcium in plasma is higher for egg production (Underwood, 1981). Calcium absorption is influenced by a protein known as a mechanism of Calcium Binding Protein (CaBP). Protein contribute to the retention of and calcium balance in the gastrointestinal tract. On duodenum protein improve the absorption of calcium (Jiang et al., 2015). Calcium is absorbed by the small intestine (about 10-30\%) in 3 forms include free ions, ion bound proteins, and ionfree insoluble. Proteins play an active role to bring calcium into the cells of the intestinal mucosa leading to blood and deposited into the network. Blood proteins in these studies are same around $6.01 \pm 0.62 \mathrm{~g} / \mathrm{dl}$ between treatments. Calcium absorption in the gastrointestinal tract may be the cause blood calcium levels between treatments become invisible influence. In the process of absorption of calcium, it can bind with fatty acids especially unsaturated fatty acid and form insoluble calcium soaps and wasted through feces (Tillman et al., 1982 and Mutucumarana et al., 2014). The fatty acids can be derived from any other feed material digestibility also increased due to the addition multienzyme. The possibility of this that caused no difference in calcium levels between treatments ducks.

Table 3. Feed Consumption, Blood Protein Level, and Eggshell Thickness in Responses

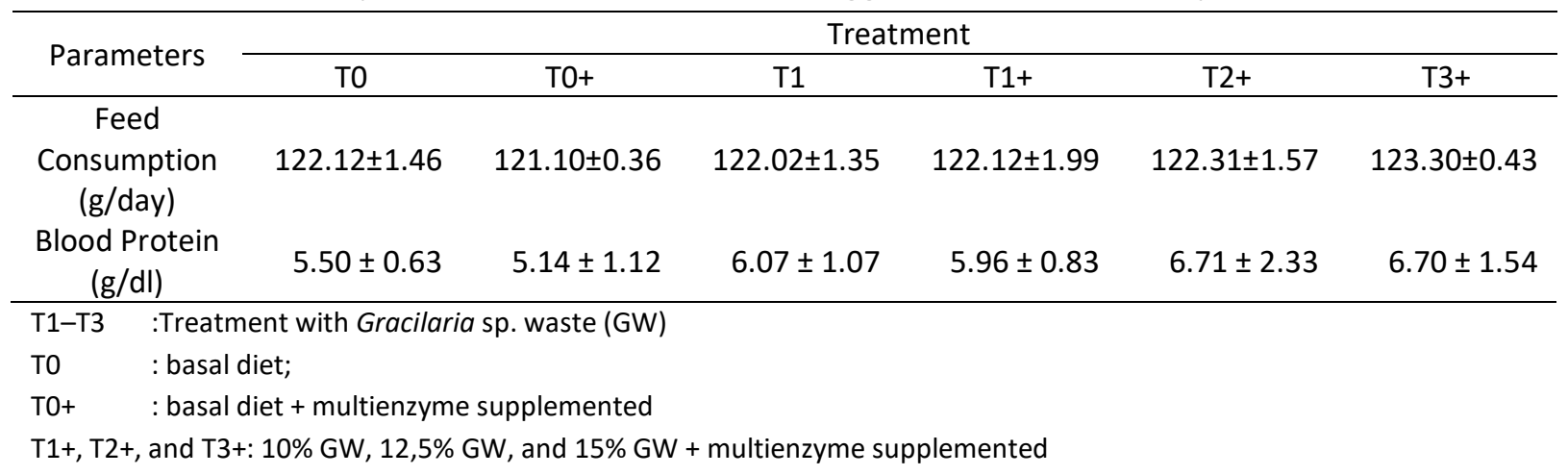


The response of other minerals such as phosphorus, sodium, potassium, and iron duck blood treated diet containing Gracilaria sp. waste revealed an increase in the level of Gracilaria sp. waste are higher. The highest blood mineral levels indicated on ration containing $15 \%$ Gracilaria sp. waste with multienzyme. This is caused by the absorption of minerals are more efficient at administration level Gracilaria sp. waste is increasing. The addition of feed materials containing higher mineral trigger digestive tract absorbs better (Rusinek-Prystupa, 2014). Minerals from organic materials will be utilized more effectively by the body poultry (Abdallah et al., 2009). Multienzyme containing NSP enzymes breaker on seaweed specific waste that presents material which is prebiotic for bacteria in the digestive tract. In addition, multienzyme also working on other feed ingredients in the ration. Multienzyme will reduce the viscosity of the gel inside of digestive tract, endogenous enzymes facilitate entry into the feed material particles and liberate the trapped nutrients (Pugh and Chalfont, 1993).

Multienzyme complexes used in this study provide a phytase enzyme that functions to break down phytic origin feed ingredients making up rations and were able to increase the availability of phosphorus in the ration (Tirajoh et al., 2009). Phosphorus has an important role in the accumulation of energy. The concentration of phosphorus in the blood closely related to the rapid growth of livestock because it produces more ATP (Ozturk et al., 2012). Phosphorus plays an important role in almost all metabolic processes of bioenergy processes, the activity of the cells, to the metabolism of carbohydrates. Diet containing Gracilaria sp. waste up to $15 \%$ had good respond to the use of mineral bodies in terms of the levels in the blood.

Sodium become essential components of physiological processes in the body. The function of keeping the concentration of sodium outside the cell while potassium in cells. The concentration of sodium between the cells to function as a driver cell transport. Sodium and potassium have an important role in regulating the balance of fluids in the body. Mineral function of sodium ( $\mathrm{Na}$ ) is the major cation found in the extracellular fluid, whereas potassium $(K)$ is the major cation in intracellular fluid. If both of these minerals are not balanced, the water will flow into or out of the cell to maintain concentrations of $\mathrm{Na}$ and $\mathrm{K}$ in order to remain balanced. This happens due to process of active transport of sodium out of cells are exchanged with the entry of potassium into cells (Na-K pumping) (Yaswir et al., 2012).

Sodium and potassium also showed an increased response to the used of Gracilaria $s p$. waste containing up to $15 \%$. Both of these minerals work as electrolytes, maintaining acidbase balance and water, regulating the osmotic pressure, also works on nerve and muscle function. Normal sodium levels in the blood of poultry by Underwood (1981) is in the range 0.12 to $0.15 \%$ and normal serum potassium according to Suttle (2010) is $130-160 \mathrm{mmol} / \mathrm{l}$. When converted approximately $1200-1500 \mathrm{ppm}$ 117.3 to 215.05 ppm of sodium and potassium. Blood levels of sodium and potassium ducks treated rations containing Gracilaria sp. waste included in the category of normal. A ration containing Gracilaria sp. waste showed a response that increases the LG higher level. The amount of sodium and potassium in the body is a reflection of the balance of sodium and potassium in and out. Entry of potassium through the gastrointestinal tract depends on the amount and type of food (Yaswir et al., 2012). At the level of the increased use of sodium followed by an increase of SCFA (Short Chain Fatty Acid) as result of carbohydrate fermentation in the digestive tract (Jankowski et al., 2012) as a source of energy. Acetate and propionate as anti-cholesterol (Tuohy et al., 2005; Quigley, 2010). The fermentation process will change the atmosphere in the digestive 
tract becomes acidic ( $\mathrm{pH} 4.5)$. Environmental causes acid lipase activity to be limited, so that the reduced fat digestion and subsequent formation of body lipid would be decreased. Decrease in blood lipid has been investigated by Frasiska (2016) showed significantly decreased results after the provision of rations containing seaweed wastes and multienzyme.

It also occurs in iron levels in the blood. The use of ration containing Gracilaria sp. waste with multienzyme tends to improve the utilization of iron are seen in the levels of iron in the blood that increases when compared with the basal ration without the use of Gracilaria waste with multienzyme. Iron serum levels of birds ranging from 20-50 ppm (Arifin, 2008 and Suttle, 2010). Duck iron serum levels in the treated ration containing Gracilaria sp. waste in this study includes normal. Iron in the body serves as the sender of oxygen to tissues and as a cofactor of several enzymes involved in energy metabolism and thermoregulation (Cabrita et al., 2016). Iron minerals in the body needed for electron transfer reactions, gene regulation, binding and oxygen transport. In addition, iron-forming red blood cells (Arifin, 2008). Iron into the components of hemoglobin and myoglobin. The use of plant species such as microalgae feed containing iron is believed to be able to cope with heat stress by increasing the levels of iron in the blood and minimize the liver to secrete more mineral and mineral concentration resulted in a decrease in the blood as a result of heat stress response (Akbari and Olfati, 2015). Iron plays an important role in the formation of blood. Function to transport blood and other nutrients circulate in the body for metabolic system.

\section{Conclusion}

A ration containing waste seaweed Gracilaria sp. up to the level of $15 \%$ plus the multienzyme give a good response in the blood mineral levels for local ducks.

\section{Acknowledgement}

This project was supported by the Minister of Research, Technology and Higher Education and Coordinating Ministry for Economic Affairs through the Master Plan of the Acceleration and Extension of Indonesian Economic Development research grant program (year 2015).

\section{References}

Abdallah AG, OM El-Husseiny, and KO Abdel-Latif. 2009. Influence of Some Dietary Organic Mineral Supplementations on Broiler Performance. International Journal of Poultry Science. 8: 291298.

Abdurrahman ZH, YB Pramono, and N Suthama. 2016. Feeding Effect Of Inulin Derived From Dahlia Tuber Combined With Lactobacillus sp. on Meat Protein Mass Of Crossbred Kampong Chicken. Journal of the Indonesian Tropical Animal Agriculture. 41(1): 37-44.

Akbari M, and A Olfati. 2015. The Effects of Different Levels of Chlorella Microalgae on Blood Biochemical Parameters And Trace Mineral Concentrations of Laying Hens Reared Under Heat Stress Condition. International Journal of Biometeorology. 60(5): 757-762.

Alamsjah MA, RF Christiana, S. Subekti. 2011. Pengaruh Fermentasi Limbah Rumput Laut Gracilaria Sp. Dengan Bacillus subtilis terhadap Populasi Plankton. Jurnal Ilmiah Perikanan dan Kelautan. 3(2): 203-213 (Article in Bahasa Indonesia)

Arifin, Z. 2008. Beberapa Unsur Mineral Esensial Mikro dalam Sistem Biologi dan Metode Analisisnya. Jurnal Litbang Pertanian. 27(3): 99105. (Article in Bahasa Indonesia)

Ariyani, Eni. 1997. Penetapan Kalsium dalam Plasma dan Serum Darah dengan Teknik AAS. Lokakarya Fungsional Non Peneliti. Balai penelitian Ternak Ciawi Bogor (Article in Bahasa Indonesia)

Cabrita AR, MR Maia, HM Oliveira, I Sousa-Pinto, AA Almeida, E Pinto, and AJ Fonseca. 2016. Tracing Seaweeds as Mineral Sources for Farm Animals. Journal of Applied Phycology. 28(5): 3135-3150.

Frasiska N, E Suprijatna, and S Susanti, 2016. Effect of Diet Containing Gracilaria Sp. Waste and Multi-Enzyme Additives on Blood Lipid Profile of Local Duck. Animal Production, 18(1): 22-29.

Haryanti AM. 2008. Kapasitas Penyerapan dan Penyimpanan Air pada Berbagai Ukuran Potongan Rumput Laut Gracilaria verrucosa sebagai Bahan Dasar Pupuk Organik. Bioma. 10(1) : 1-6 (Article in Bahasa Indonesia) 
$\mathrm{Hu}$, Bin, Qianhong Gong, Ye Wang, Yiming Ma, Jingbao Li, and Wengong Yu. 2006. Prebiotic Effects of Neoagaro-Oligosaccharides Prepared by Enzymatic Hydrolysis of Agarose. Anaerobe, 12(5): 260-266.

Jankowski J, J Juśkiewicz, K Lichtorowicz, and Z Zduńczyk. 2012. Effects Of The Dietary Level And Source Of Sodium On Growth Performance, Gastrointestinal Digestion And Meat Characteristics In Turkeys. Animal Feed Science and Technology. 178(1): 74-83.

Jiang MJ, JP Zhao, HC Jiao, XJ Wang, Q Zhang, and H Lin. 2015. Dietary Supplementation with Sodium Bicarbonate Improves Calcium Absorption and Eggshell Quality of Laying Hens During Peak Production. British Poultry science. 56(6): 740747

Kiarie E, LF Romero, and CM Nyachoti. 2013. The Role of Added Feed Enzymes in Promoting Gut Health in Swine and Poultry. Nutrition Research Reviews. 26(1): 71-88.

Ministry of Trade. 2013. Rumput Laut Indonesia. Warta Ekspor. Jakarta.

Mutucumarana KR, V Ravindran, G Ravindran, and J Cowieson. 2014. Influence of Dietary Calcium Concentration on the Digestion of Nutrients along the Intestinal Tract of Broiler Chickens. The Journal of Poultry Science. 51(4): 392-401.

Ochoa L, JDJP Michel, and J Olmos-Soto. 2013. Complex Carbohydrates as A Possible Source of High Energy to Formulate Functional Feeds. Advances in Food and Nutrition Research. 73: 259-288.

Oktavia Y, A Andhikawati, T Nurhayati, and K Tarman. 2014. Karakterisasi Enzim Kasar Selulase Kapang Endofit dari Lamun. Jurnal Ilmu dan Teknologi Kelautan Tropis. 6(1): 209-218 (Article in Bahasa Indonesia)

Ozturk E, N Ocak, A Turan, G Erener, A Altop , and S Cankaya. 2012. Performance, Carcass, Gastrointestinal Tract and Meat Quality Traits, and Selected Blood Parameters of Broilers Fed Diets Supplemented With Humic Substances. Journal of the Science of Food and Agriculture. 92(1): 59-65.

Patel S, and A Goyal. 2011. Functional Oligosaccharides: Production, Properties And Applications. World Journal of Microbiology And Biotechnology. 27(5): 1119-1128.

Pranata, A. R. 2015. Profil Kalsium dan Fosfor Plasma Darah Itik pada Perbedaan Imbangan Elektrolit Ransum Itik yang Dipelihara Intensif Pada Kondisi Minim Air. Students e-Journal 4(2): 1-7

Pugh R, and Chalfont. 1993. The Scope For Enzymes In Comercial Feed Formulations. Asia Pasific Lecture Alltech. Nicholasville, Kentucky (Research Report)
Quigley EM. 2010. Prebiotics and Probiotics: Modifying and Mining the Microbiota. Pharmacological Research. 61(3): 213-218.

Rusinek-Prystupa E, J Lechowski, W ZukiewiczSobczak, P Sobczak, and K Zawislak. 2014. Influence of Citrosept Addition to Drinking Water and Scutellaria Baicalensis Root Extract on The Content of Selected Mineral Elements in Blood Plasma of Turkey Hens. Annals of Agricultural and Environmental Medicine, 21(3): 595-600.

Shields RJ, and I Lupatsch. 2012. Algae for Aquaculture and Animal Feeds. J Anim Sci. 21: 23-37.

Sinulingga M, S Darmanti. 2007. Kemampuan Mengikat Air oleh Tanah Pasir yang Diperlakukan Dengan Tepung Rumput Laut Gracilaria Verrucosa. Jurnal Anatomi Fisiologi. 15(2): 32-38 (Article in Bahasa Indonesia)

Suttle Neville F. 2010. Mineral Nutrition of Livestock $4^{\text {th }}$ Edition. Cabi Press. London. 587 pages

Tillman AD, H Hari, R Soedomo, P Soeharto, L Soekanto. 1982. Ilmu Makanan Ternak Dasar. UGM Press, Yogyakarata. 422 pages

Tirajoh S, WG Piliang, and PP Ketaren. 2014. Suplementasi Enzim Pemecah Serat dan Fitase terhadap Performans Ayam Broiler. Indonesian Journal of Animal and Veterinary Sciences. 19(3): 40-46 (Article in Bahasa Indonesia)

Tuohy KM, GCM Rouzaud, WM Bruck, and GR Gibson. 2005. Modulation of The Human Gut Microflora Towards Improved Health Using Prebiotics-Assessment of Efficacy. Current Pharmaceutical Design. 11(1): 75-90.

Underwood, Eric. J. 1980. The Mineral Nutrition of Livestock. Commonwealth Agricultural Bureaux, Scottland.

Wang JP, JD Kim, JE Kim, and IH Kim. 2013. Amino acid digestibility of single cell protein from Corynebacterium ammoniagenes in growing pigs. Animal Feed Science and Technology. 180(1): 111-114.

Wu S.C., TN Wen, and CL Pan. 2005. Algaloligosacharides-lysates Preparen by Two Bacterial Agarase Stepwise Hydrolyzed and Their Anti-oxidative Properties. Fisheries Science. 71(5): 1149-1159

Yaswir R, and I Ferawati. 2012. Fisiologi dan Gangguan Keseimbangan Natrium, Kalium dan Klorida serta Pemeriksaan Laboratorium. Jurnal Kesehatan Andalas. 1(2): 80-85 (Atricle in Bahasa Indonesia).

Yunita WK, W Sarengat, and E Suprijatna. 2015. Fermented Seaweed (Gracilaria verrucosa) Waste Flour on Layer Japanese Quail (Coturnix coturnix japonica). Animal Agricultural Journal, 4(1) :121-126. (Article in Bahasa Indonesia). 